\title{
Expansion of Eucalyptus Woodlots in the Fertile Soils of the Highlands of Ethiopia: Could It Be a Treat on Future Cropland Use?
}

\author{
Birru Yitaferu ${ }^{1}$, Anteneh Abewa ${ }^{1} \&$ Tadele Amare ${ }^{1}$ \\ ${ }^{1}$ Amhara Agricultural Research Institute (ARARI), Bahr Dar, Ethiopia \\ Correspondence: Birru Yitaferu, Amhara Regional Agricultural Research Institute, P.O.Box 527, Bahr Dar, \\ Ethiopia. Tel: 251-912-027-600. E-mail: birru_yitaferu2002@yahoo.com
}

Received: May 22, 2013 Accepted: June 20, 2013 Online Published: July 15, 2013

doi:10.5539/jas.v5n8p97 URL: http://dx.doi.org/10.5539/jas.v5n8p97

\begin{abstract}
A study was conducted to assess the effect of land use change from eucalyptus to cropland on soil physico-chemical properties and perceptions of farmers in Koga irrigation area, Amhara Region. Soil samples were taken from 4 sites of three land uses (eucalyptus woodlots, cropland, and eucalyptus land use changed to cropping) and at 0-20, 20-40 and 40-60 cm depths. The three depths were used for analysis of soil chemical properties, whereas the first two depths for physical properties. Furthermore, randomly selected 15 farmers were interviewed for their perception on the state of soil fertility and crop yield conditions on lands that were recently changed from eucalyptus to cropland. The result showed that except for available $\mathrm{P}$, sampled plots that were changed from eucalyptus to cropland were found better in soil chemical properties ( $\mathrm{pH}, \mathrm{N}, \mathrm{CEC}$ ) and SOM contents as compared to croplands. As compared to the other two land uses, total $\mathrm{N}$ was found larger at eucalyptus woodlots. Regarding soil physical properties (bulk density and texture), little or no difference was recorded among the different land use types. On top of that, farmers perceived that plots that were under eucalyptus have better fertility, require less nitrogen fertilizer and crops perform well compared to plots that are contineously under cropping. Thus, results of this study confirmed that changing land use from eucalyptus to cropland is possible without detrimental effect on soil properties and without affecting productivity of lands to raise crops.
\end{abstract}

Keywords: eucalyptus, land use, land use change, Koga, Mecha District, soil physico-chemical property

\section{Introduction}

In Ethiopia, each year about 80,000 ha of natural forests have been converted to farmland, while 50,000 ha of woodlands removed for charcoal production and farmland expansion; and 30,000 ha of woodland, thickets, and bushes cleared for fuel wood production (UNDP/ World Bank, 1988 cited in Tola, 2009). Ethiopia has a sad story on its forest resources. Both Emperor Kaleb and Minilik II were very concerned on the forest resources and Emperor Menelik, assisted by his French technical advisor, introduced fast-growing tree species from southern Europe (Portugal, Italy, Greece, etc.), whereas later on Eucalyptus is assumed introduced from Australia that made up of several species. Eucalyptus was first introduced with the objectives of meeting ever-increasing demand for construction poles and firewood in Addis Ababa, the seat of King Menelik II (Yitebitu, 2010; Amare, 2010).

The radius of Eucalyptus growing from the capital city - Addis Ababa continued to increase during the first decade. The next stage of Eucalyptus growing outside Addis Ababa was by missionaries in Ghimbi, DebreTabor, and Harar. Later still, especially after the 50s, Eucalyptus growing moved to rural areas from these first nodes, being planted first in urban areas, the homesteads and eventually on agricultural lands by farmers and urban dwellers (Amare, 2010).

Today, while the debates among experts continue on its alleged ecological disadvantages, eucalyptus plantation is showing an amazing expansion in Amhara Region in particular and in Ethiopia in general by smallholder farmers. At the moment, Ethiopia has the largest area of Eucalyptus plantations (more than 0.5 million ha) (Amare, 2010) in East Africa and is one of the 10 pioneer countries that introduced the eucalyptus trees (Gessesse \& Tekilu, 2011).

The preference to eucalypt by small holder farmers is due to a number of advantages gained from the tree. The tree species are preferred more than others due to their fast-growth, coppicing ability, easy silvicultural management, 
poorly palatable to animals, the demand for its wood products with reasonable prices, and their adaptations to a wide range of ecological conditions (Yitebitu, 2010; Mulugeta, 2010).

Even if it is claimed for its ecological disadvantage, in Mecha district fertile croplands have been converted to eucalyptus wood lots each year for two main reasons; its attractive economic return with minimal labor and capital inputs, and fear of crop yield reduction at the adjacent or neighboring eucalyptus woodlots to crop farms. In Ethiopian, still natural forests have been converted to croplands and croplands to eucalyptus woodlots in small land holdings, however, unless for a special reason, there is no land use change from eucalyptus to cropland. This might be due to the long existing fear of the alleged negative impacts of eucalyptus to soil physico-chemical properties that could cause reduction on crop yields.

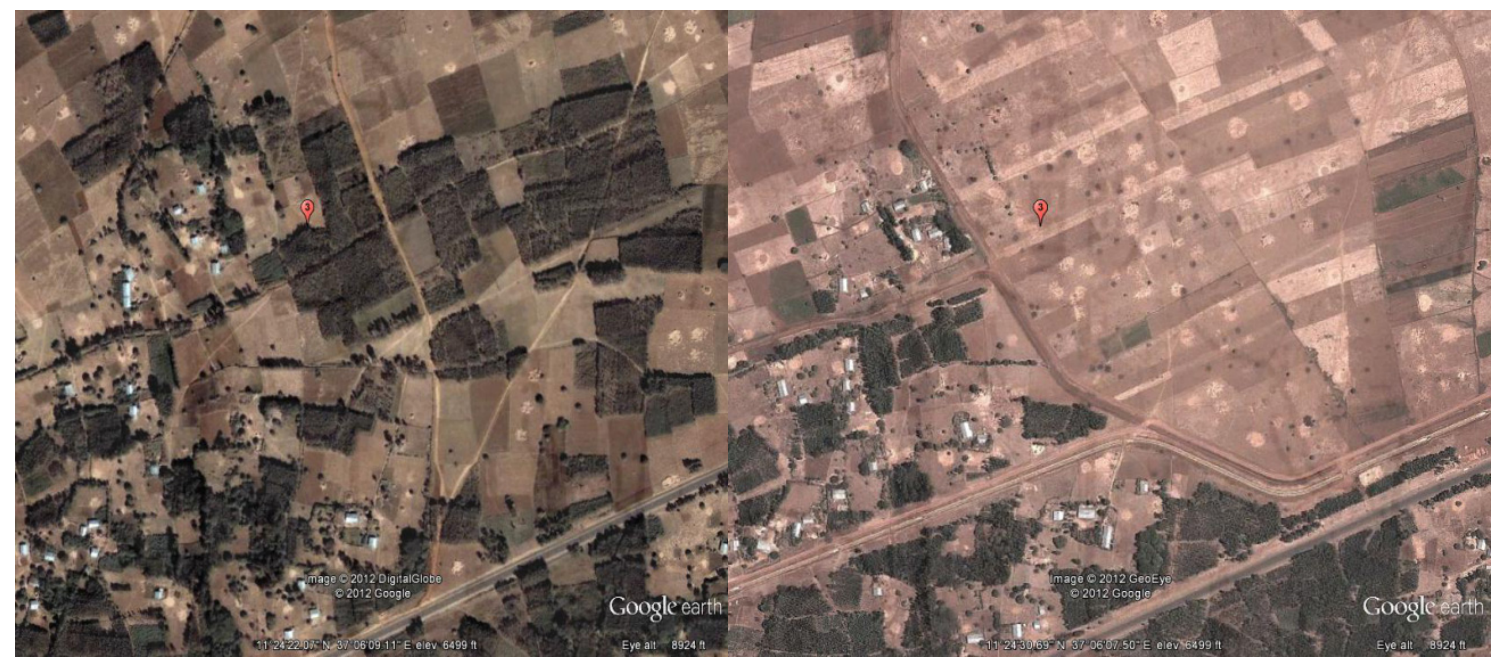

Figure 1. Eucalyptus woodlot from one of the sampling site (Left, Google earth image in 2009) before excavation and after excavation (right, Google earth image in 2011)

Even if a wealth of information is available on eucalyptus, critics on the effect of eucalyptus on soil and water depletion, allelopathic effect to nearby plants and the difficulty on the future land use change to crop use are still debating. The authors were seriously questioned on what would be the fate of those fertile croplands that have been changed to eucalyptus if the need arises to change back to cropping after four or five tree harvest. Fortunately, very recently, a land use conversion was made from eucalyptus woodlots to irrigated cropping at the Koga irrigation scheme in the Amhara Region where the objective of this study could be addressed. Even though farmers in the area are much interested in continuing with eucalyptus plantation, the Koga irrigation scheme is entirely dedicated for production of food crops so as to meet part of the national food security objectives. Therefore, this study is aimed at meeting the objectives on investigating the effects of land use change from eucalyptus to cropland on soil physico-chemical properties and on evaluating the farmers' opinion on land productivity problems faced due to the present land use change. Figure 1 shows the location of the Koga irrigation scheme and the excavation process on the eucalyptus woodlots that changed to cropland.

\section{Materials and Methods}

\subsection{Description of the Study Area}

Koga irrigation scheme is situated in Mecha district, West Gojam Zone, Amhara Regional State of Ethiopia close to Merawi town - the center of the district, which lies about $35 \mathrm{~km}$ southwest of the regional capital Bahir Dar. Mecha district is located at $11^{\circ} 10^{\prime} \mathrm{N}$ to $11^{\circ} 25^{\prime} \mathrm{N}$ latitude and $37^{\circ} 02^{\prime} \mathrm{E}$ to $37^{\circ} 17^{\prime} \mathrm{E}$ longitude at an altitude ranging from 1,900 to 3,200 masl. The mean annual rainfall at Merawi town is $1589 \mathrm{~mm}$ and mean temperature is $16-20^{\circ} \mathrm{C}$ (Nigusssie \& Yared, 2010), and is subject to the inter-tropical convergence zone. This leads to a single rainy season during the months between June/July to September/October allowing for only one rain fed cropping season, referred to as Meher in Ethiopia. The dominant soil type in the scheme is Nitisols. Koga irrigation scheme is designed to supply irrigation water for more than 7,000 ha of land. 


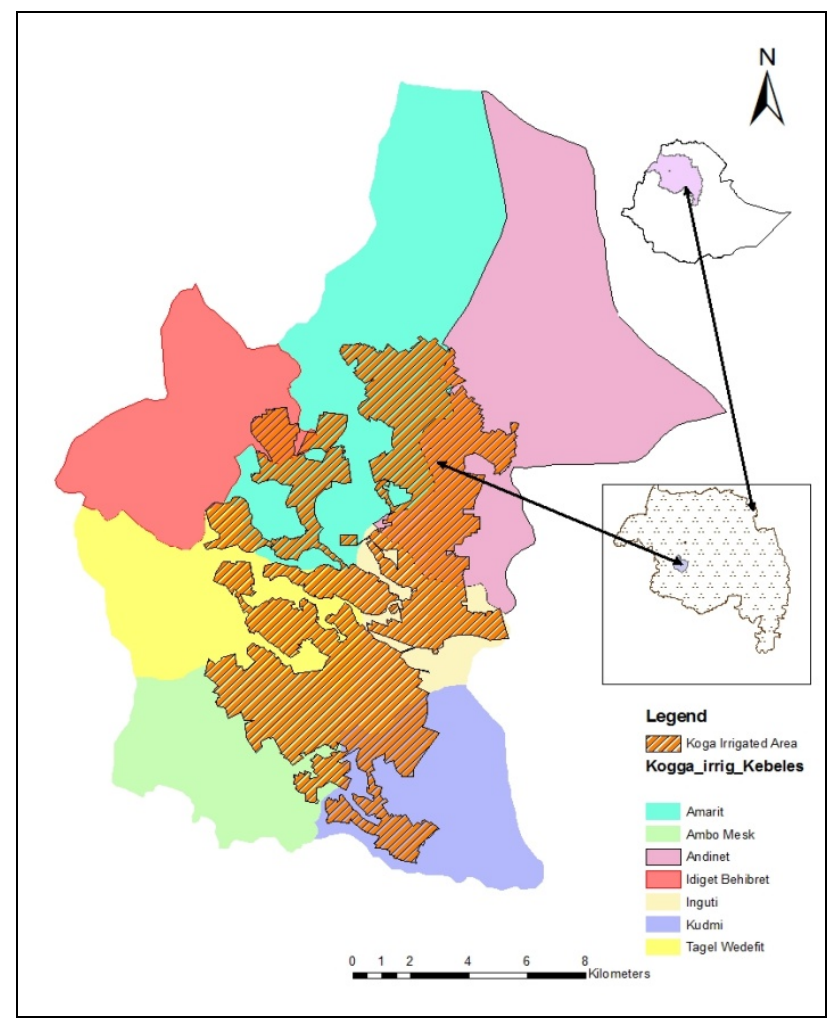

Figure 2. Koga irrigation scheme overlaid on the Kebele Administrations where the irrigation scheme found

\subsection{Soil Sampling}

In this study, three land use types: 1) cultivated land, 2) Eucalyptus plantation 3) eucalyptus woodlots changed to croplands were selected. For each land use, four sites were selected randomly (considered as replications), for soil sampling. Soil samples were taken from $0-20 \mathrm{~cm}$ and $20-40 \mathrm{~cm}$ for bulk density (24 soil samples) and $0-20 \mathrm{~cm}$, $20-40 \mathrm{~cm}$ and $40-60 \mathrm{~cm}$ for other parameters (36 soil samples); a total of 60 soil samples were taken and used for the study.

\subsection{Soil Preparations and Analysis}

The samples were oven-dried at $105^{\circ} \mathrm{C}$ for bulk density determination. Soil-water content was determined by gravimetrically. For chemical analysis and textural analysis soil samples were air dried under shade, ground using pestle \& mortar and sieved to pass through $2 \mathrm{~mm}$. Particle size analysis was determined by hydrometic method as described by Sahilemedhin and Taye (2000). The soil $\mathrm{pH}$ was determined using glass electrode $\mathrm{pH}$ meter in 1:2.5 soil to water suspension following the procedure outlined by Sahlemedihn and Taye (2000). The organic carbon content was analyzed by wet digestion method using the Walkley and Black procedure (Nelson \& Sommers, 1982) and converted to soil organic matter by multiplying it by the factor of 1.724 . The total nitrogen was determined by Kjeldahl method (Bremner \& Mulvaney, 1982), Available phosphorus was determined according to Bray II method ( Sahilemedhin \& Taye, 2000).

\subsection{Farmer's Perception on the Effect of Land Use Changes from Eucalyptus Woodlot to Cropland.}

Farmers perception on eucalyptus land use before excavation and after excavation/changed to cropland and its productivity as compared to croplands that were constantly used for long years was assessed through semi structured interviews made in 4 Kebbeles (the smallest administrative unit) and different irrigation blocks. A purposive random sampling was made for 15 farmers who have farmlands changed from eucalyptus to cropland use. The respondent answer summarized in tabular form, analyzed in descriptive statistics and incorporated as a part of research result in this paper.

\subsection{Statistical Data Analysis}

The impact of independent variables such as land use on the dependent variables (soil properties) was statistically tested. Analysis of variance (ANOVA) was carried out using SAS software (SAS, 2008). For 
variables showing statistically significant difference between treatments $(\mathrm{p}<0.05)$, further analysis of mean separation was carried out using Duncan's Multiple Range Test (DMRT) at 5\% probability.

\section{Results and Discussion}

\subsection{Soil Physical Properties}

Bulk density $\left(\mathrm{g} \mathrm{cm}^{-3}\right)$ showed no significant difference between the different land uses for the surface $0-20 \mathrm{~cm}$ and $20-40 \mathrm{~cm}$ depths (Table 1). In terms of absolute value, however, cropland had the highest bulk density of $1.11 \mathrm{~g}$ $\mathrm{cm}^{-3}$ in $0-20 \mathrm{~cm}$ and $1.24 \mathrm{~g} \mathrm{~cm}^{-3}$ in $20-40 \mathrm{~cm}$ depth of the soil. Soil under eucalyptus woodlots and land use changed from eucalyptus to cropland had similar bulk density, both exhibited lower bulk densities as compared to cropland in both depths (Table 1). This result is in agreement with Fekadu et al. (2012) who reported similar results for Wondo Gent area in Ethiopia as bulk density didn't show significant difference between the different land uses and soil depths with the range of $\left(0.93-1.07 \mathrm{~g} \mathrm{~cm}^{-3}\right)$. Again Tilashwork et al. (2012) also found that in Koga irrigation watershed, soils bulk densities at all depths and distances from Eucalyptus camaldulensis and Croton macrostachyus stands are low and ranged from 1.0 to $1.1 \mathrm{~g} \mathrm{~cm}^{-3}$. The lower bulk density in crop lands as compared to eucalyptus plantation also reported by (Yihenew \& Getachew, 2013). The lower bulk density under eucalyptus may be due to organic matter accumulation and les trampling by livestock. As noted by Kimmins (1997), structure, texture, and porosity of soils, together with their organic matter content, combined to together to determine bulk density of a soil. All land utilization types are in good condition on their bulk density. For good plant growth, bulk densities need to be below $1.4 \mathrm{~g} \mathrm{~cm}^{-3}$ for clays soils (Miller \& Donahue, 1997).

Table 1. Mean of bulk density $\left(\mathrm{g} \mathrm{cm}^{-3}\right)$ in the soil layer of $0-20$ and $20-40 \mathrm{~cm}$ and soil textural class in $0-20,20-40$ and 40-60 $\mathrm{cm}$ depths and across different land uses

\begin{tabular}{|c|c|c|c|c|c|c|c|}
\hline \multirow{2}{*}{ LUT } & & \multirow{2}{*}{$\begin{array}{l}\text { Depth } \\
\text { (cm) }\end{array}$} & \multirow{2}{*}{$\begin{array}{l}\text { Bulk Density } \\
\left(\mathrm{g} \mathrm{cm}^{-3}\right)\end{array}$} & \multicolumn{3}{|c|}{ Soil texture \% } & \multirow{2}{*}{ Textural class } \\
\hline & & & & Sand & Silt & Clay & \\
\hline \multirow{3}{*}{\multicolumn{2}{|c|}{ Eucalyptus }} & $0-20$ & 1.07 & 18.28 & 26.32 & 55.40 & Clay \\
\hline & & $20-40$ & 1.17 & 12.28 & 21.32 & 66.40 & Clay \\
\hline & & $40-60$ & - & 11.92 & 16.41 & 71.67 & Clay \\
\hline \multirow{3}{*}{\multicolumn{2}{|c|}{ Cropland }} & $0-20$ & 1.11 & 17.56 & 25.00 & 57.44 & Clay \\
\hline & & $20-40$ & 1.24 & 16.28 & 12.32 & 71.40 & Clay \\
\hline & & $40-60$ & - & 13.36 & 14.00 & 72.64 & Clay \\
\hline \multirow{3}{*}{$\begin{array}{l}\text { Recently } \\
\text { cropland } \\
\text { eucalyptus) }\end{array}$} & \multirow{3}{*}{$\begin{array}{l}\text { converted } \\
\text { (previous }\end{array}$} & $0-20$ & 1.08 & 18.28 & 27.32 & 54.40 & Clay \\
\hline & & $20-40$ & 1.16 & 13.14 & 21.23 & 65.63 & Clay \\
\hline & & $40-60$ & & 13.9 & 14.2 & 71.9 & Clay \\
\hline
\end{tabular}

The soil texture analysis result showed that sand and clay didn't show significant difference $(\mathrm{P}>0.05)$ across land uses whereas, silt texture showed significant difference $(\mathrm{P}<0.01)$. Similarly, sand texture showed significant difference $(\mathrm{P}<0.05)$, whereas silt and clay $(\mathrm{P}<0.01)$ across depth. Sand and silt texture decreased down a depth whereas clay increased (Figure 3).

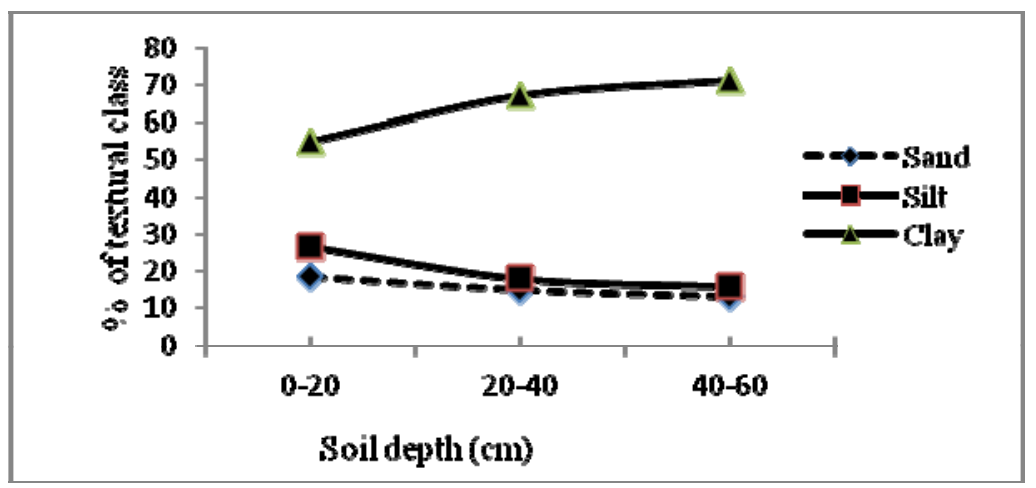

Figure 3. Percent of soil texture across soil depths 
The soil textural analysis result against the land use and soil depths are presented in Table 1. Clay texture was dominated all over the land uses and depths ranged from 54.75 to $73.11 \%$. The silt fraction was ranged from $12.32 \%$ in croplands with the depth of $20-40 \mathrm{~cm}$ and it was $27.32 \%$ in $0-20 \mathrm{~cm}$ depth under land use change from eucalyptus to cropland. Nevertheless, sand and silt decreases down a depth whereas clay content increases down a depth in all the three land uses. All land uses and depths of the soils in this study were fund dominated by the clay fraction. In areas like Koga, where the soil texture is dominated by clay, lower bulk density is reliable for seed germination and crop growth. Clay texture has good CEC as compared to other textural classes. In general, fine-textured soils hold more water and plant nutrients and thus require less frequent applications of water, lime, and fertilizer (Daniels \& Haering, 2011). Soils with high clay content (more than $40 \%$ ), however, hold less plant available water than loamy soils. Fine textured soils have a narrower range of moisture conditions under which they can be worked satisfactorily than sandy soils. Soils with silt and clay content may puddle or form surface crusts after rains, impeding seedling emergence. High clay soils often break up into large clods when worked in either too dry or too wet conditions.

\subsection{Soil Chemical Properties}

\subsubsection{Soil $\mathrm{pH}$ and Exchangeable Acidity}

Some important soil chemical properties of the soils under different land uses were significantly different and some were not. For instance, soil $\mathrm{pH}$ for the three land use types showed statistically significant different $(\mathrm{P}<0.05)$, whereas exchangeable acidity didn't show significant difference. All land uses exhibited acidity, although the soil under Eucalyptus showed even a relatively lower $\mathrm{pH} 5.20$ and higher exchangeable acidity $(0.78)$ as compared to the land use changed from eucalyptus to crop $\left(5.51 \mathrm{pH}\right.$ and $\left.0.66 \mathrm{cml}_{\mathrm{c}} \mathrm{kg}^{-1} \mathrm{EA}\right)$ and croplands $(5.41 \mathrm{pH}$ and 0.60 $\mathrm{cml}_{\mathrm{c}} \mathrm{kg}^{-1} \mathrm{EA}$ ) value (Table 2). Even if, the $\mathrm{pH}$ of the area is recognized as acidic, the land use changed to cropland, however, showed an improvement in soil $\mathrm{pH}$ by 0.29 unit and a reduction of EA by $0.12 \mathrm{cml}_{\mathrm{c}} \mathrm{kg}^{-1}$ as compared to soils under eucalyptus land cover. This might be due to litter and root biomass decomposition could raise and release some cations. Robson and Abbott (1989) discussed that soils are extremely heterogeneous with large variations in $\mathrm{pH}$ in short distances due to root activity, decomposition of organic matter, nitrification, etc. The other reason for lower $\mathrm{pH}$ in eucalyptus woodlots could be high Cation uptake by the tree and removal of cations with the frequent harvest of tree. As reported by Binkley et al. (1992), intensive management, including frequent harvesting of high nutrient content aboveground biomass can lower the availability of all soil nutrients and lead to soil acidification. The third reason for low $\mathrm{pH}$ could be high rainfall of the area that could leach cations to deeper horizons and/or depleting the rhizosphare. As reported by Pritchett and Fisher (1987) when leaching of acid soils proceeds over time, the proportion of exchangeable $\mathrm{Al}^{3+}$ and $\mathrm{H}^{+}$ions on clay and humus increases, whereas the proportion of exchangeable $\mathrm{Ca}^{2+}, \mathrm{Mg}^{2+}$ and $\mathrm{K}^{+}$decreases.

Our result is in line with the findings of different authors; Lalisa et al. (2010) and Yihenew and Getachew (2013) reported that in Ethiopian central highlands that soil $\mathrm{pH}$ is lower in wood lots/eucalyptus plantation as compared to homestead, croplands and grazing lands. Zerfu (2002) also noted that eucalyptus globulus plantation sites showed high level of active acidity or low $\mathrm{pH}$ as compared to agricultural lands.

Table 2. Mean soil chemical properties under different land uses

\begin{tabular}{llllllll}
\hline LUT & $\begin{array}{l}\text { Sample } \\
\text { size }(\mathrm{N})\end{array}$ & $\begin{array}{l}\mathrm{pH} \\
(1: 2.5 \text { Water })\end{array}$ & $\mathrm{OM}(\%)$ & $\mathrm{N}(\%)$ & $\begin{array}{l}\mathrm{P} \\
\mathrm{ppm}\end{array}$ & $\begin{array}{l}\mathrm{CEC} \\
\left(\mathrm{cmlo}_{\mathrm{c}} \mathrm{kg}^{-1}\right)\end{array}$ & $\begin{array}{l}\text { Ex-acidity } \\
\left(\mathrm{cmlo}_{\mathrm{c}} \mathrm{kg}^{-1}\right)\end{array}$ \\
\hline Eucalyptus & $\mathrm{n} 1$ & $5.20 \mathrm{~b}$ & $3.21 \mathrm{a}$ & 0.18 & 14.94 & 21.33 & 0.78 \\
Continuous Crop & $\mathrm{n} 2$ & $5.41 \mathrm{a}$ & $2.86 \mathrm{~b}$ & 0.15 & 17.96 & 20.69 & 0.60 \\
Recently cropland & $\mathrm{n} 3$ & $5.51 \mathrm{a}$ & $3.36 \mathrm{a}$ & 0.15 & 16.27 & 21.45 & 0.66 \\
\hline Probability & - & $*$ & $*$ & $* *$ & $\mathrm{Ns}$ & $\mathrm{Ns}$ & $\mathrm{Ns}$ \\
CV $(\%)$ & & 4.02 & 11.20 & 11.48 & 22.22 & 13.42 & 38.8 \\
\hline
\end{tabular}

** significant $(\mathrm{P} \leq 0.01),{ }^{*}$ significantly different at $\mathrm{P} \leq 0.05$ and ns denotes for not significantly different.

The $\mathrm{pH}$ of the soil showed significant difference $(\mathrm{P}<0.05)$ with depths. The lower $\mathrm{pH} 5.25$ was found in deeper soils $(40-60 \mathrm{~cm})$ at permanently croplands and recently converted croplands, whereas the highest $\mathrm{pH}$ that was recorded in the intermediate depth $(20-40 \mathrm{~cm})$ at all land uses except there is about 0.14 unit lower at the eucalyptus woodlots (Figure 4). 


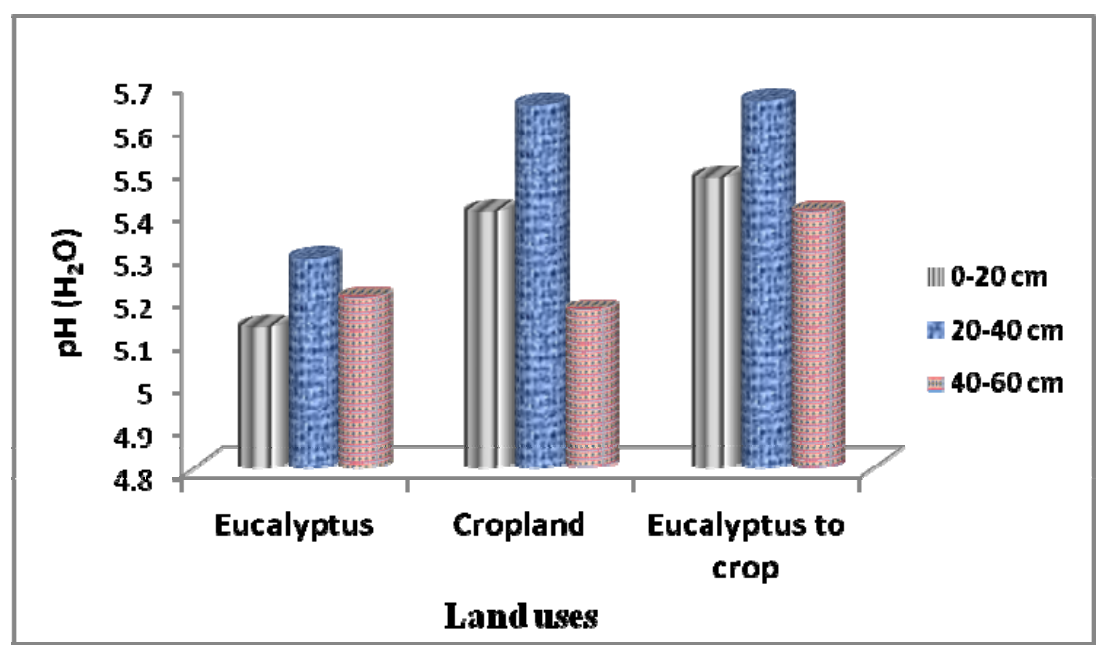

Figure 4. Soil pH as influenced by interaction of land use and soil depth

\subsubsection{Organic Matter}

Organic matter showed statistically significant difference $(\mathrm{P}<0.05)$ on land use types and soil depths. Land use change from eucalyptus to cropland showed higher organic matter content up to $3.36 \%$ than the two land use types (Table 2). Croplands had the lowest OM content (2.86); this could be due to a complete removal of crop residues for animal feeds and fire wood. This result is in agreement with Lalisa et al. (2010) that organic carbon is lowest in cereal fields as compared to other land uses in the central highlands of Ethiopia.

As shown in Table 3, organic matter decreased down a soil depth. Larger OM (3.65\%) was found in the surface soil (0-20 cm depth) followed by $3.07 \%$ at $20-40 \mathrm{~cm}$ and $2.71 \%$ in the $40-60 \mathrm{~cm}$ depths. The highest OM up to $3.91 \%$ and $3.64 \%$ were recorded on land use changed from eucalyptus to cropland and under eucalyptus land use at $0-20 \mathrm{~cm}$, respectively. However, the lowest OM $(2.36 \%)$ was recorded on croplands at $40-60 \mathrm{~cm}$ soil depth (Figure 4).

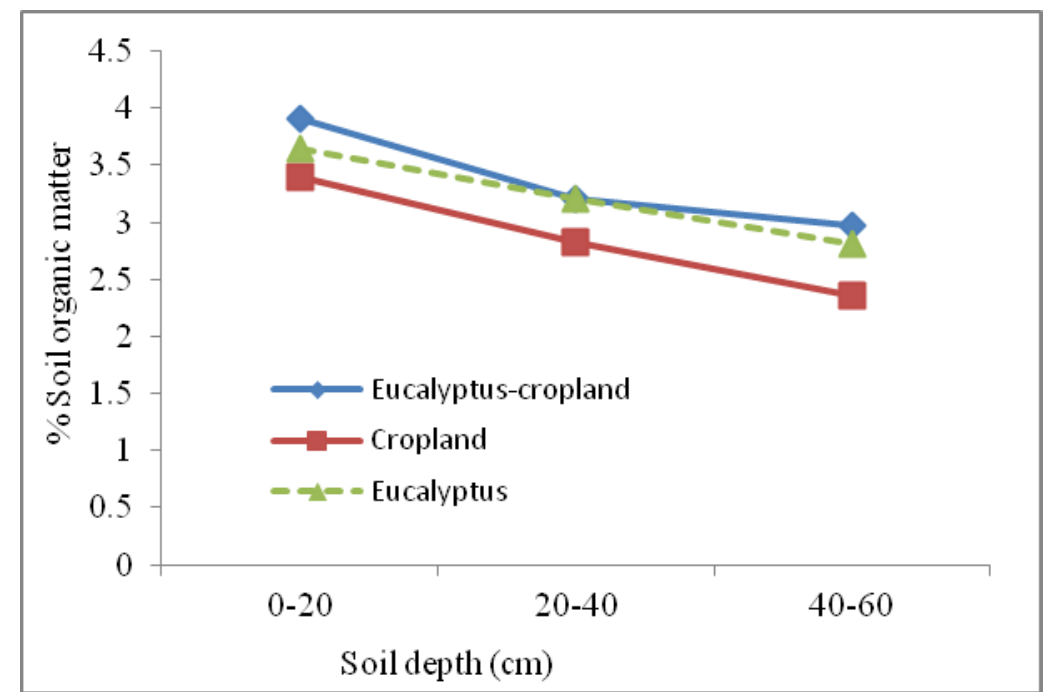

Figure 5. Soil OM distribution in different land uses and soil depths

This result is confirmed by Muluneh (2011) that soil under eucalyptus at Jufi site of Achefer district, Ethiopia showed a decrease in soil organic matter down a depth. Lelisa et al. (2010) also showed that organic carbon content of the soils at homestead, cereal farm and wood lots/eucalyptus land uses is found lower with soil depths. It is obvious that high accumulation of organic matter can be found in the surface soil where large amount of root 
biomass and other plant debris can be found. Trees generally improve ground cover, add organic matter to the soil, reduce the erosive impact of falling rain and improve infiltration of water into the soil (Jagger \& Pender, 2000).

Table 3. Mean soil chemical properties under different soil depths

\begin{tabular}{lllllll}
\hline Depth & $\begin{array}{l}\mathrm{pH} \\
(1: 2.5 \text { Water })\end{array}$ & OM (\%) & $\mathrm{N}(\%)$ & $\begin{array}{l}\text { Av.P } \\
(\mathrm{ppm})\end{array}$ & $\begin{array}{l}\mathrm{CEC} \\
\left(\mathrm{cmol}_{\mathrm{c}} \mathrm{kg}^{-1}\right)\end{array}$ & $\begin{array}{l}\text { Ex-acidity } \\
\left(\mathrm{cmol}_{\mathrm{c}} \mathrm{kg}^{-1}\right)\end{array}$ \\
\hline $0-20$ & $5.34 \mathrm{~b}$ & $3.65 \mathrm{a}$ & $0.16 \mathrm{~b}$ & 16.83 & 21.29 & 0.61 \\
$20-40$ & $5.53 \mathrm{a}$ & $3.07 \mathrm{~b}$ & $0.15 \mathrm{c}$ & 16.25 & 21.05 & 0.64 \\
$40-60$ & $5.25 \mathrm{~b}$ & $2.71 \mathrm{c}$ & $0.17 \mathrm{a}$ & 16.08 & 21.15 & 0.80 \\
\hline Probability & $*$ & $* *$ & $* *$ & $\mathrm{~ns}$ & $\mathrm{~ns}$ & $\mathrm{Ns}$ \\
CV $(\%)$ & 4.02 & 11.20 & 11.48 & 22.22 & 13.42 & 38.8 \\
\hline
\end{tabular}

** significant $(\mathrm{P} \leq 0.01)$, * significantly different at $\mathrm{P} \leq 0.05$ and ns denotes for not significantly different.

\subsubsection{Total Nitrogen}

Significant difference $(\mathrm{P}<0.01)$ in total nitrogen content of the soils were found due to LUTs and soil depths. Total nitrogen was as much as $0.18 \%$ under eucalyptus plantation, whereas it was $0.15 \%$ on both cropland and land use changed from eucalyptus to cropland (Table 2). The rise of total $\mathrm{N}$ under eucalyptus might be the presence of higher organic matter in the surface whereas the low $\mathrm{N}$ content in the croplands may be due to high decomposition rate on the plow surface and high N uptake of the cereal crops. Davidson (1993) also reported that a substantial proportion of the nutrients in a tree crop held in the foliage which is returned periodically to the soil. This nutrient turnover is responsible for improvement of soil fertility by plantations established on previously cleared sites. Maintenance of the nutrient cycle is critical to the long term productivity of soils and it is essential foliage and leaf litter are not removed from the site. Even greater benefits accrue if bark is also left behind the relative amounts of nutrients in different parts of the biomass of E. tereticornis in India (Davidson, 1993). Sanginga and swift (1992) reported that in Zimbabwe the Eucalyptus plot had higher $\mathrm{NH}_{4}-\mathrm{N}$ contents than the Miombo woodland and bare soil/croplands. Soils under Eucalyptus forests also reported as it has larger soil nitrogen due to the long period of time under tree cover and soil nitrogen mineralization could be increased under Eucalyptus forests by 11-14 ppm per year (Reversat, 1988; John et al., 2005; Muluneh, 2011). A study result by Lalisa et al. (2010), in central highlands of Ethiopia, indicated that total $\mathrm{N}$ was lower in cereal farm as compared to pasture land and wood lots. Even if Tilashwork et al. (2012) discussed that total N (TN) increased with distance from the eucalyptus trees, their result showed that near the Eucalyptus stand the TN was significantly larger $(\mathrm{p} \leq 0.01)$ of the average $\mathrm{TN}$ of the field and the nitrogen content declines with increasing distance up to $5 \mathrm{~m}$ away from the tree. Generally higher $\mathrm{N}$ near eucalyptus trees might be due to the higher $\mathrm{N}$ in the foliage of eucalyptus and low uptake by the tree. This was discussed by Selamyhun (2004) that foliage of eucalyptus accounted $45-48 \%$ of total $\mathrm{N}$ from above ground parts but the mean annual nitrogen accumulation of eucalyptus ranged from $8-13 \mathrm{Kg} \mathrm{N} \mathrm{ha}^{-1} \mathrm{y}^{-1}$. The other reason for high $\mathrm{N}$ under eucalyptus woodlots might be due to the low temperature and very limited radiation reached on the surface of the soil that leads to low volatilization of $\mathrm{NH}_{3}-\mathrm{N}$.

$\mathrm{N}$ content was also found increased significantly with the soil depth $(\mathrm{P}<0.01)$. The higher total $\mathrm{N}(0.17 \%)$ was found on the $40-60 \mathrm{~cm}$ depth range, whereas total $\mathrm{N}$ content was $0.16 \%$ and $0.15 \%$ at $0-20 \mathrm{~cm}$ and $2040 \mathrm{~cm}$ soil depths. The interaction effect of depth with land use on total $\mathrm{N}$ also showed significant differences $(\mathrm{P}<0.01)$. Total $\mathrm{N}$ was very low $(0.11 \%)$ in $20-40 \mathrm{~cm}$ soil layer at a land use where changes from eucalyptus to crop, whereas higher $\mathrm{N}$ up to $0.19 \%$ was found in $20-40 \mathrm{~cm}$ depths under eucalyptus land use followed by $0.18 \%$ on cropland at 40-60 cm soil depth. Total $\mathrm{N}$ increased down a depth on croplands, whereas at eucalyptus woodlots showed an increase in the middle zone $(20-40 \mathrm{~cm})$. Contrary to croplands, total $\mathrm{N}$ at $20-40 \mathrm{~cm}$ depth declined in a land use changed from eucalyptus to crop. This could be due to the leaching of $\mathrm{N}$ to lower depth and removal of the nutrient by annual crops on the surface soil. It is also known that in cereal dominated farming system, competition for nutrient is higher in the surface layer due to the root biomass on this layer is much denser than the other layers. On the other hand, higher $\mathrm{N}$ on surface soil under eucalyptus could be the large amount of root biomass of the tree is found in lower or sub surface horizons of the soil. Selamyhun (2004) pointed out after eight years, fine roots $(<10$ $\mathrm{mm}$ diameter) accounting for $80 \%$ of the total root mass per unit area are mostly extend laterally to less than $20 \mathrm{~m}$ lateral distance and 60-100 cm depth in to the adjacent cropland areas in Nitisols of the central highlands of Ethiopia. 


\subsubsection{Available Phosphorus}

Generally, the phosphorus content of the area is very low. Available P didn't show statistically significant difference $(\mathrm{P}>0.05)$ due to land uses, whereas croplands had relatively better phosphorus $(18.07 \mathrm{ppm})$ as compared to lands covered by eucalyptus woodlots (14.94 ppm) and land use changed from eucalyptus to cropland (16.27 ppm). The larger available $\mathrm{P}$ in croplands might be due to the cumulative effects of application of phosphorus containing fertilizer in the past.

Similar finding is reported by Yechale and Solomon (2011) that the amount of available p content in croplands is much larger than in forest and eucalyptus woodlots. Woldeamlak and Stroosnijder (2003) also reported that the available $\mathrm{P}$ content of cultivated fields is larger than forest lands, which suggests that the annual leftover of $\mathrm{P}$ from fertilizer application is much larger than obtained from leaf decomposition from trees. Lisanework and Michelsen (1994) explained that the lower available P content at forest lands is due to a high proportion of $\mathrm{P}$ is retained and immobilized by microbes. Another possible reason for low available $\mathrm{P}$ under eucalyptus woodlots could be due to the lower $\mathrm{pH}$ conditions that can permanently fix phosphorus. Under acid conditions, phosphorus is precipitated as Fe or Al phosphates of low solubility (Tisdale et al., 2002), whereby maximum availability of phosphorus generally occurs in a $\mathrm{pH}$ range of 6.0 to 7.0. It was also found that under eucalyptus plantation, exchangeable $\mathrm{Al}$ is relatively higher than the two land uses. The raise of $\mathrm{Al}$ may lead to $\mathrm{Al}$ toxicity and lowering the soil $\mathrm{pH}$. In this study, land use changed from eucalyptus to cropland suggests that the effect of removing the eucalyptus woodlots and replacing this with annual crops was not negatively affect on availability of phosphorus. A similar study in tropical India showed that insignificant change in available P following deforestation (Saikh et al., 1998 as cited by Yechale \& Solomon, 2011).

In general, there is evidence in the literature suggesting that eucalyptus may enhance some soil conditions, including moisture and topsoil retention, particularly on degraded or barren sites through leaf litter (Jagger \& Pender, 2000). In higher plantation area like Mecha district, almost all leaf litter fall down under eucalyptus, which may pump nutrients from deeper parts of the soils through their roots to the litter that will give rise nutrients. Even after harvest some tree growers used to collect the leaves and twigs for in-situ burning before new shoots /coppice emerged. Soil nutrient levels under eucalyptus plantations can also be improved by leaving litter uncollected, adjusting spacing and mixing eucalyptus species with leguminous plants (Tesfaye, 2009). In addition, Davidson (1995) showed that eucalyptus species have a beneficial effect on soil structure and soil fertility improvement through decayed litter. Similarly, Yitebtu (2010) found that after 8 years of plantation, availability of macronutrients like phosphorous, potassium, calcium and magnesium are increased by $57 \%, 13 \%$, $31 \%$ and $45 \%$, respectively.

\subsubsection{Cation Exchanging Capacity (CEC)}

CEC didn't show statistical differences ( $P>0.05$ ) between LUTs (Table 2). In terms of absolute value, however, land use changed from eucalyptus to cropland had relatively larger CEC $\left(21.45 \mathrm{cmol}_{\mathrm{c}} \mathrm{kg}^{-1}\right)$ and under eucalyptus land use, it was about $21.32 \mathrm{cmol}_{\mathrm{c}} \mathrm{kg}^{-1}$, whereas the lower CEC $\left(20.69 \mathrm{cmol}_{\mathrm{c}} \mathrm{kg}^{-1}\right)$ was obtained on croplands. CEC on depth and interaction of land use with depth also didn't show statistical differences. The CEC of all the land uses were very acceptable, and indicates that the soils of the area are relatively fertile. Our result is confirmed by (Lalisa et al., 2010) that CEC didn't show any significant difference among the land uses in the central highlands of Ethiopia. Yechale and Solomon (2011) also confirmed that there was no statistically significant difference between soils among the land uses in terms of the CEC that was studied in the Hare river watershed, Ethiopia.

\subsection{Farmers Perception on Land Use Change from Eucalyptus to Cropland}

From the 15 farmers interviewed, 11 of them appreciated eucalyptus planting on croplands is economically important than other land uses. Considering eucalyptus as an asset is also found the most important by many farmers. They believed that eucalyptus assumed as money deposited in a bank. The other benefits according to the respondents were, the labor required to produce eucalyptus is minimal. On the contrary, two respondents appreciated the cropland use due to its frequent and immediate return to investments as compared to tree growing. Only one respondent said that as there is no economical difference between crop and tree growing. Another respondent said that eucalyptus and croplands should be used according to the fertility status of the soil; for poor soil, eucalyptus is more preferable than growing it on fertile soils that are suitable for crops.

Except one, all farmers appreciated changing eucalyptus land use to cropland due to better yields obtained on such lands. Even though farmers recognized that the crop yield is better at the recently converted croplands, no one could tell the exact difference quantitatively. From the respondents, five of them recognized that fertilizer amount required for the formerly eucalyptus land use as compared to contineous croplands is somehow lower. Four farmers were replied as they reduced the fertilize use by a quarter. Although most farmers perceived that 
eucalyptus land changed to cropland can give better yield than the continuously cropped lands, they were not interested to change their eucalyptus land to cropland for a simple reason that labor and input requirements for producing food grains are cumbersome.

The other important thing as of many farmers and intellectuals, fourteen of respondents didn't assume that eucalyptus could be for cropland. They considered eucalyptus land use can only be used for eucalyptus otherwise it is a waste land; this is because they have experience as there is limited vegetation undergrowth in eucalyptus woodlots and the detrimental effect on the adjacent crops (shading effect). They also assumed that eucalyptus can deteriorate the soil and this deteriorated soil cannot be re-used for cropping after excavation of the eucalyptus.

Finally for the question "what if the decision is left for you whether you change the land use to crop or left as it is despite the irrigation water available to your farm"; nine of the respondents $(60 \%)$ replied as they will change to cropping, four responded (26.67\%) will leave eucalyptus as it is, whereas two (13.33\%) respondents said they will excavate according to the soil fertility status for cropping. However, many agreed that whenever there is labor scarcity for the routine irrigation activity, prefer eucalyptus production than cropping. On the contrary, in case labor is not a limit, they preferred changing the land use from eucalyptus to cropland since irrigation farming pays much better than tree cropping.

\section{Conclusions}

The existing assumption on the environmental consequences of eucalyptus plantation is that the tree is detrimental to soil fertility and ground water, whereby future land use change to cropping is unlikely. In attesting this a study was conducted to determine the effects of land use change from eucalyptus to cropland on soil physico-chemical properties and to assess farmers' perception and opinion on the actual problems faced due to changing their land use from eucalyptus to growing food crops.

Results of the soil chemical properties indicate that except available $\mathrm{P}$ all the analyzed parameters at the land use changed from eucalyptus to cropland (in the last three years) were found better than the lands permanently under food crops. This newly changed land use is also better in its soil acidity and exchangeable acidity status than the lands under eucalyptus woodlots. The larger $\mathrm{P}$ on existing croplands could be the carry-over effect of the phosphorus fertilizers that could have been applied for the annual crops.

Farmers in the study area recognized that land use changed from eucalyptus to cropland had a yield advantage than from the plots under contineously under cropping and again the former land use requires lower amount of nitrogen fertilizer. Therefore, it is possible to conclude that changing land uses from eucalyptus to cropland has no detrimental effect on soil fertility and productivity of crops. Thus, the result confirmed that one can shift his/her eucalyptus woodlot to crop production as the need arises. However, mmonitoring the soil physico-chemical properties due to land use change from eucalyptus to cropland need to be accompanied by agronomic trials so as to depict the soil conditioning effect of tree cropping.

\section{Acknowledgements}

This paper is based on the framework of the Swiss National Centre of Competence in Research (NCCR) North-South: Research Partnerships for Mitigating Syndromes of Global Change. Our thanks go to the Amhara Agricultural Research Institute (ARARI) for all supports and facilitations provided during the course of the research. We also appreciate farmers in the Koga irrigation scheme for their understanding while we walked and dug in their farms.

\section{References}

Amare, G. (2010). Eucalyptus farming in Ethiopia: The case of Eucalyptus farm and village woodlots in Amhara Region. In L. Gil, W. Tadesse, E. Tolosana, \& R. López (Eds.) Eucalyptus species management, history, status and trends in Ethiopia (pp. 65-74). Proceedings from the congress held in Addis Ababa. September 15-17, 2010. Addis Ababa, Ethiopia.

Binkley, D., Dunkin, K. A., Dobell, D., \& Ryan, M. G.,( 1992). Production and nutrient cycling in mixed plantation of Eucalyptus and Albizia in Hawaii. Forest Science, 38, 393-408.

Bremner J. M., \& Mulvaney, C. S. (1982). Nitrogen Total. In A. L. Page, R. H. Miller, \& D. R. Keeney (Eds.), Methods of Soil Analysis, 2, 95-624. Madison: American society of agronomy.

Daniels, W. L., \& Haering, K. C. (2011). General Soil Principles. In M. Goatley Jr., \& K. Hensler (Eds), Urban nutrient management hand book. Virginia Cooperative Extension. Retrieved from http://www.hort.vt.edu/Documents/FoxUrbNutMgmt.pdf 
Davidson, J. (1993). Ecological aspects of eucalyptus plantations. Proceedings of regional expert consultation on eucalyptus. Volume I. Retrieved from http://Fao.Org/Docrep/005/Ac777e/Ac777e06.Htm

Davidson J. (1995). The eucalyptus dilemma: arguments for and against eucalyptus planting in Ethiopia. FRC Seminar Notes Series No. 1. Addis Ababa, Ethiopia.

EPA. (2012). National report of ethiopia, the United Nations conference on sustainable development (Rio+20). Addis Ababa, Ethiopia. pp. 91-103. Retrieved March, 2013, from www.http://sustainabledevelopment.un.org/content/documents/973ethiopia.pdf

FAO. (1988). The eucalypts dilemma. Rome, Italy.

Fekadu, G., Abdu, A., Mulugeta, L., \& Aramde, F. (2012). Effects of different land uses on soil physical and chemical properties in Wondo Genet area, Ethiopia. N. Y. Sci. J., 5(11), 110-118. Retrieved from www.academia.edu/.../Effects_of_Different_Landuses_on_Soil_Physical.pdf

Gessesse, D., \& Teklu, E. (2011). Eucalyptus in East Africa, socio-economic and environmental issues. Planted forests and trees working papers. Working paper 46/e, forest management team, forest management division 30pp. FAO, Rome. Retrieved November, 2012, from www.http://fao.org/docrep/014/am332e/am332e00.pdf

Jagger, P., \& Pender, J. (2000). The role of trees for sustainable management of less favored lands: The Case of Eucalyptus in Ethiopia. EPTD discussion paper no. 65. International food policy research institute, Washington, DC. Retrieved from http://www.ifpri.org/sites/default/files/publications/eptdp65.pdf

Kimmins, J. P. (1997). Forest Ecology. A foundation for sustainable management (2nd ed., p. 596). New Jersey.

Lalisa, A., Herbert, H., \& Monika, S. (2010). Effects of land use types on soil chemical properties in smallholder farmers of central highland Ethiopia. Ekologia (Bratislava), 29(1), 1-14. Retrieved from www.http//dx.doi.10.4149/ekol_2010_01_1.pdf

Miller, R. W., \& Donhue, R. L. (1997). Soil in our environment (7th ed., 1001pp). Prentice-Hal.

Mulugeta, L. (2010). Growing eucalypt by smallholder farmers. In L. Gil, W. Tadesse, E. Tolosana, \& R. López (Eds.), Eucalyptus species, management, history, status and trends in Ethiopia. Proceedings from the conference held in Addis Ababa. September $15^{\text {th }}-17^{\text {th }}, 2010$.

Muluneh, M. (2011). Eucalyptus plantations in the highlands of ethiopia revisited: a comparison of soil nutrient status after the first coppicing. Master thesis. Mountain forestry program institute of forest ecology University of natural resources and life sciences Vienna, Austria. Retrieved from www.https://zidapps.boku.ac.at/download._eucalyptus_in-the_highlands_of_ethiopia.pdf

Nelson, D. W., \& Sommers, L. E. (1982). Total carbon, organic carbon and organic matter. In A. L. Page (Ed.), Methods of Soil Analysis. Part 2: Chemical and Microbiological Properties Agron. 9, pp. 539-579, . Madison, Wisconsin

Nigusssie, T., \& Yared, A. (2010). Effect of land use/land cover management on koga reservoir sedimentation. Nile basin capacity building network. Cairo, Egypt. Retrieved from http://www.nbcbn.com/Project_Documents/Progress_Reports_2010/Local_Actions/Ethiopia-local-2010.pdf

Pritchett, W. L., \& Fisher, R. F. (1987). Properties and Management of Forest soils (2nd ed.). New York: John Wiley \& sons.

Robson, A. D., Abbott, L. K. (1989). The effect of soil acidity on microbial activity in soils. In A. D. Robson (Ed.), Soil acidity and plant growth (pp. 139-165). Australia: Academic Press.

Sahilemedhin, S., \& Taye, B. (2000). Procedures for soil and plant analysis technical paper. National Soil Research Center, Ethiopian Agricultural Research Organization, Addis Ababa, Ethiopia.

Sanginga, N., \& Swift, M. J. (1992). Nutritional effects of eucalyptus litter on the growth of maize (Zea mays). Agric. Ecos.vszems Environ., 41, 55-65. Retrieved from ftp://ftp.aphis.usda.gov/foia/FOLDER_10/AR00036938\%20Sangiga\%20and\%20Switt\%201992.pdf

SAS. (2008). SAS/STAT 9.2 software. Cary, NC: SAS Institute Inc.

Selamyihun, K. (2004). Using eucalyptus for soil and water conservation on the highland vertisols of Ethiopia. $\mathrm{PhD}$ Thesis, Wageningen University. The Netherlands.

Tesfaye, T. (2009). Is eucalyptus ecologically hazardous tree species? Ethiopian e-journal for research and innovation foresight, 1(1), 128-134. 
Tilasshwork, C., Collick, A. S., Adgo, E., Lehmann, C. J., \& Steenhuis, T. S. (2013). Eco-hydrological impacts of Eucalyptus in the semi humid Ethiopian Highlands: the Lake Tana Plain. Journal of Hydrology and Hydromechanics, 61(1), 21-29b. http://dx.doi.org/10.2478/johh-2013-0004

Tisdale, S., Nelson, W., Beaton, J., \& Havlin, J. (2002). Soil fertility and fertilizers (5th ed.). N.J., USA: Prentice-Hall, Inc., Englewood Cliffs.

Tola, G. (2009). Prospects of sustainable natural resource managmement and livelihood development in Wondo Genet area, southern Ethiopia. MSc thesis. Addis Ababa Univerisity.

Woldeamlak, B., \& Stroosnijder, L. (2003). Effects of agro ecological land use succession on soil properties in Chemoga watershed, Blue Nile basin, Ethiopia. Geoderma, 111, 85-98. http://dx.doi.org/10.1016/S0016-7061(02)00255-0

Yechale, K., \& Solomon Raju, A. J. (2011). Effect of land use/land cover change on soil properties in the hare river watershed, Ethiopia. The Ecoscan, 5(1\&2), 69-74. Retrieved from http://www.theecoscan.in/Journal_pdf/51\&214\%20YECHALE\%20KEBEDE.pdf

Yihenew, G. S., \& Getachew, A. (2013). Effects of different land use systems on selected physico-chemical properties of soils in Northwestern Ethiopia. Journal of agricultural science, 5(4), 112-120. Retrieved from http//:dx:doi:10.5539/jas.v5n4p112

Yitebitu, M. (2010). Eucalyptus trees and the environment: a new perspective in times of climate change. In L. Gil, W. Tadesse, E. Tolosana, \& R. López (Eds.), Eucalyptus species management, history, status and trends in Ethiopia (pp. 104-113). Proceedings from the Congress held in Addis Ababa. September 15-17, 2010. Addis Ababa, Ethiopia.

Zerfu, H. (2002). Ecological impact evaluation of eucalyptus plantations in comparison with agricultural and grazing land use types in the highlands of Ethiopia. Doctoral thesis: Institute of Forest Ecology, University of Natural Resources and Life Sciences, Vienna.

\section{Copyrights}

Copyright for this article is retained by the author(s), with first publication rights granted to the journal.

This is an open-access article distributed under the terms and conditions of the Creative Commons Attribution license (http://creativecommons.org/licenses/by/3.0/). 